J. Appl. Glycosci., 54, 165-168 (2007)

(C) 2007 The Japanese Society of Applied Glycoscience

Regular Paper

\title{
Improved Radical Scavenging Activity of $\beta$-Lactoglobulin-xylobiose Modified by the Maillard Reaction
}

\author{
(Received February 15, 2007; Accepted March 2, 2007)

\begin{abstract}
Kensuke Yajima, ${ }^{1}$ Shuichi Onodera, ${ }^{1}$ Yasuyuki Takeda, ${ }^{1}$ Isao Kato ${ }^{1}$ and Norio Shiomi ${ }^{1, *}$
\end{abstract} \\ ${ }^{1}$ Department of Food and Nutrition Sciences, Graduate School of Dairy Science Research, Rakuno Gakuen University \\ (582, Bunkyoudai, Midorimachi, Ebetu 069-8501, Japan)
}

\begin{abstract}
Lactoglobulin ( $\beta$-LG) was modified and conjugated to xylobiose using the Maillard reaction. The antioxidant activity of the Maillard reaction product, $\beta$-LG-xylobiose, was measured in vitro and compared to that of conjugated $\beta$-LG-lactose. The reaction for 7 days led to conjugated $\beta$-LG-xylobiose with a relative molecular mass ranging between 19 and $22 \mathrm{kDa}$ based on SDS-PAGE analysis. It is confirmed that xylobiose bound to $\beta$-LG by gas-liquid chromatography. One milligram of conjugated $\beta$-LG-xylobiose contains $108 \mu \mathrm{g}$ of xylobiose, while the available $\varepsilon$-amino group content decreased to $40 \%$ after the Maillard reaction. Conjugated $\beta$-LG-xylobiose had a higher radical scavenging activity than free $\beta$-LG. As the modification by xylobiose had a higher efficiency than the modification by lactose, it is found that xylobiose is a useful oligosaccharide for protein modification. Furthermore, the radical scavenging activity of $\beta$-LG was improved by modification with xylobiose.
\end{abstract}

Key words: $\quad \beta$-lactogloblin, xylobiose, Maillard reaction, modification, radical scavenging activity

Milk, especially bovine milk, is widely consumed, and is processed into various foods such as cheese and butter. Whey, the main residue of dairy industries, contains appreciable amounts of proteins such as $\beta$-lactoglobulin $(\beta$ LG), $\alpha$-lactoalbumin and immunoglobulin. ${ }^{1}$ Although many approaches to utilize the whey proteins have been tried, the uses of the proteins are limited. From a technological perspective, one of the most frequently encountered problems with milk is the non-enzymatic browning that results from the Maillard reaction, especially at high temperatures during thermal treatments. The reaction occurs between milk proteins and lactose, the most abundant milk sugar. In this reaction, reducing sugars react with an amino acid to produce a Schiff base and an Amadori compound in the first steps, and then advanced glycated end-products (AGEs), including melanoidins, in the end stages.

It has been revealed that change the nutritive and physical functions of protein were improved by the Maillard reaction, and many studies have examined this process. For example, it was reported that protein modifications improved emulsion stability, ${ }^{2-5}$ changed the denaturation temperature of protein, $\left.{ }^{6}\right)$ had positive effects on the immune system, ${ }^{7-9)}$ affected calcium transport in Caco-2 cells, ${ }^{10,11)}$ and changed functional properties of carp myosin. ${ }^{12)}$ The antioxidant activity of protein also could be improved by the Maillard reaction. ${ }^{13,14)}$

On the other hand, functional oligosaccharides used as modifiers have not been extensively studied. In fact, no studies have been done using xylobiose as a modifier in the Maillard reaction. Xylo-oligosaccharide positively influences enterobacterial flora, and is preferentially utilized

${ }^{*}$ Corresponding author $($ Tel. +81-11-388-4754, Fax. +81-11-3875848, E-mail: n-shiomi@rakuno.ac.jp). by $B$. adolescentis, $B$. infantis and B. longum as an energy source. ${ }^{15)}$

In our preliminary study, it was found that xylobiose could react with protein faster than maltose and lactose. This study was done (i) to develop a new food resource using whey proteins, especially $\beta$-LG, (ii) to improve whey protein function via the Maillard reaction, and (iii) to investigate radical scavenging activity of $\beta$-LGxylobiose.

\section{MATERIALS AND METHODS}

Materials. $\quad \beta$-lactoglobulin ( $\beta$-LG) from bovine milk was purchased from Sigma (St. Louis, MO, USA). Xylobiose was purchased from Towa Chemical Industry Co., Ltd. (Tokyo, Japan). Lactose was purchased from Nacalai Tesque (Kyoto, Japan).

Preparation of $\beta-L G$-xylobiose conjugate. $\quad \beta-L G$ and saccharides were dissolved in $0.2 \mathrm{M}$ phosphate buffer $(\mathrm{pH}$ 7.8), and the final concentration of $\beta-\mathrm{LG}$ and the saccharide were adjusted to $5 \mathrm{mg} / \mathrm{mL}$. The solution was frozen at $-40^{\circ} \mathrm{C}$ and lyophilized in a freeze-dryer (FD-81, Tokyo Rika Kikai Co., Ltd., Tokyo, Japan) for 4 days to obtain a powder. The lyophilized powders were incubated at $40^{\circ} \mathrm{C}$ and $30-40 \%$ relative humidity in the incubator (MIR152, Sanyo Electric Co., Ltd., Osaka, Japan), and were kept under these conditions for 1,4 and 7 days. To remove unreacted saccharides, conjugated $\beta$-LG-xylobiose was dissolved in distilled water and dialyzed for 3 days against distilled water. Subsequently, solutions were ultrafiltrated at $3000 \mathrm{rpm}$ for $10 \mathrm{~min}$ using centriprep YM10 (Millipore Co., Billerica, MA, USA). This process was repeated three times.

SDS-PAGE analysis. Conjugated $\beta$-LG-xylobiose was assessed with SDS-polyacrylamide gel electrophoresis 
(SDS-PAGE) according to the method of Laemmli ${ }^{16}$ using 15\% acrylamide slab gel and 3.75\% acrylamide stacking gel. Coomassie Brilliant Blue R-250 (Nacalai Tesque, Kyoto, Japan) was used for protein staining.

Matrix assisted laser desorption ionization time of flight mass spectrometry (MALDI TOF-MS) analysis.

MALDI TOF-MS spectra were obtained on a ShimadzuKratos mass spectrometer (Kompact Probe) using sinapic acid (Sigma, St. Louis, MO, USA) as a matrix.

Detection of hydrolysate from $\beta-L G$-xylobiose by GLC. Conjugated $\beta$-LG-xylobiose was dissolved in $1 \mathrm{~mL}$ of $2 \mathrm{M}$ trifluoroacetic acid at a concentration of $10.0 \mathrm{mg} /$ $\mathrm{mL}$. The sample was heated at $100^{\circ} \mathrm{C}$ for $3 \mathrm{~h}$, filtered using filter paper, and then evaporated using Rotavapor R200 (Büchi Labortechnic AC, Flawil, Switzerland). Afterwards, $0.2 \mathrm{~mL}$ of trimethylsilylimidazole (GL Sciences Inc., Tokyo, Japan) was added to the solution, and boiled for $10 \mathrm{~min}$, and this solution was chromatographed on GL8 apparatus (Shimadzu Corporation, Kyoto, Japan) equipped with an SE-52 (Chromosorb W) column.

Measurement of xylobiose in $\beta-L G$-xylobiose conjugate. The amount of xylobiose in the conjugated $\beta$-LGxylobiose was determined using the phenolsulfuric acid method. ${ }^{17)}$

Measurement of available E-amino group content.

The available $\varepsilon$-amino group content present in conjugated $\beta$-LG-xylobiose was determined spectrophotometrically using $o$-phthalaldehyde and $N$-acetyl-L-cysteine. ${ }^{18)}$

Measurement of the scavenging effects of DPPH radicals. The scavenging effect was measured according to the method of the DPPH test described by Chevalier ${ }^{2)}$ with slight modifications.

\section{RESULTS AND DISCUSSION}

\section{Analysis of relative molecular mass.}

The SDS-PAGE analysis showed that the relative molecular mass $\left(M_{\mathrm{r}}\right)$ of $\beta$-LG was increased by the Maillard reaction (Fig. 1), and that conjugated $\beta$-LG-xylobiose incubated for 7 days had higher $M_{\mathrm{r}}$ than other conjugated entities produced earlier in the reaction course (Fig. 1, lane 6), although each conjugated $\beta$-LG-xylobiose was observed as a broad band (Fig. 1, lane 4-6). It is thought that the band thickness of conjugated $\beta$-LG-xylobiose is due to differences in the $M_{\mathrm{r}}$, since the Maillard reaction occurs randomly and at unequal levels in the lyophilized powder. The $M_{\mathrm{r}}$ of native $\beta$-LG was approximately 18

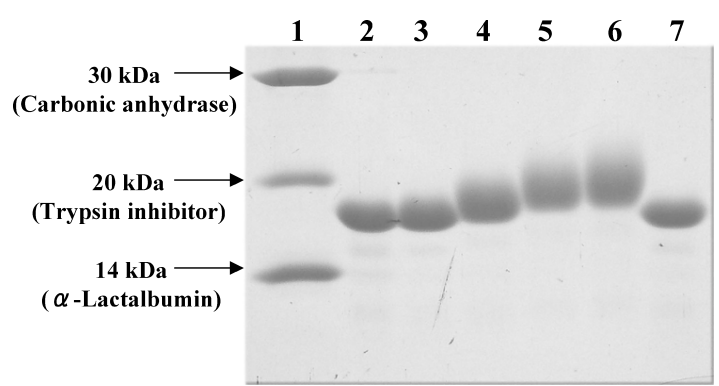

Fig. 1. SDS-PAGE of conjugated $\beta$-LG-xylobiose.

Lane 1, protein markers; lane 2 and 7, native $\beta$-LG; lane 3 to 6 , the mixture of $\beta$-LG and xylobiose incubated for 0 (lane 3), 1 (lane 4), 4 (lane 5) and 7 (lane 6) days.
$\mathrm{kDa}$, and the apparent $M_{\mathrm{r}}$ of conjugated $\beta$-LG-xylobiose obtained after 7 days' incubation was estimated to be in the range between 19 and $22 \mathrm{kDa}$.

The same results were obtained by matrix assisted laser desorption ionization time of flight mass spectrometry (MALDI TOF-MS) (Fig. 2). The most abundant molecular species had the $M_{\mathrm{r}}$ of $21 \mathrm{kDa}$, and the $M_{\mathrm{r}}$ was distributed from 20 to $22 \mathrm{kDa}$ after 7 days' reaction. These results implied that 10 or more xylobiose molecules could bind to a $\beta$-LG molecule.

\section{Detection of hydrolysate by gas-liquid chromatography (GLC).}

Although the results from SDS-PAGE and MALDI TOF-MS analysis showed that the $M_{\mathrm{r}}$ of conjugated $\beta$-LGxylobiose increased, it was not confirmed whether a unit of xylobiose was conjugated. Then, the hydrolysate of conjugated $\beta$-LG-xylobiose was compared with that of conjugated $\beta$-LG-xylose successfully produced in the same manner. GLC analysis showed that two peaks identified as xylose were detected from the hydrolysate of conjugated $\beta$-LG-xylobiose (Fig. $3 \mathrm{C}$ ), while the peaks were not observed from conjugated $\beta$-LG-xylose treated
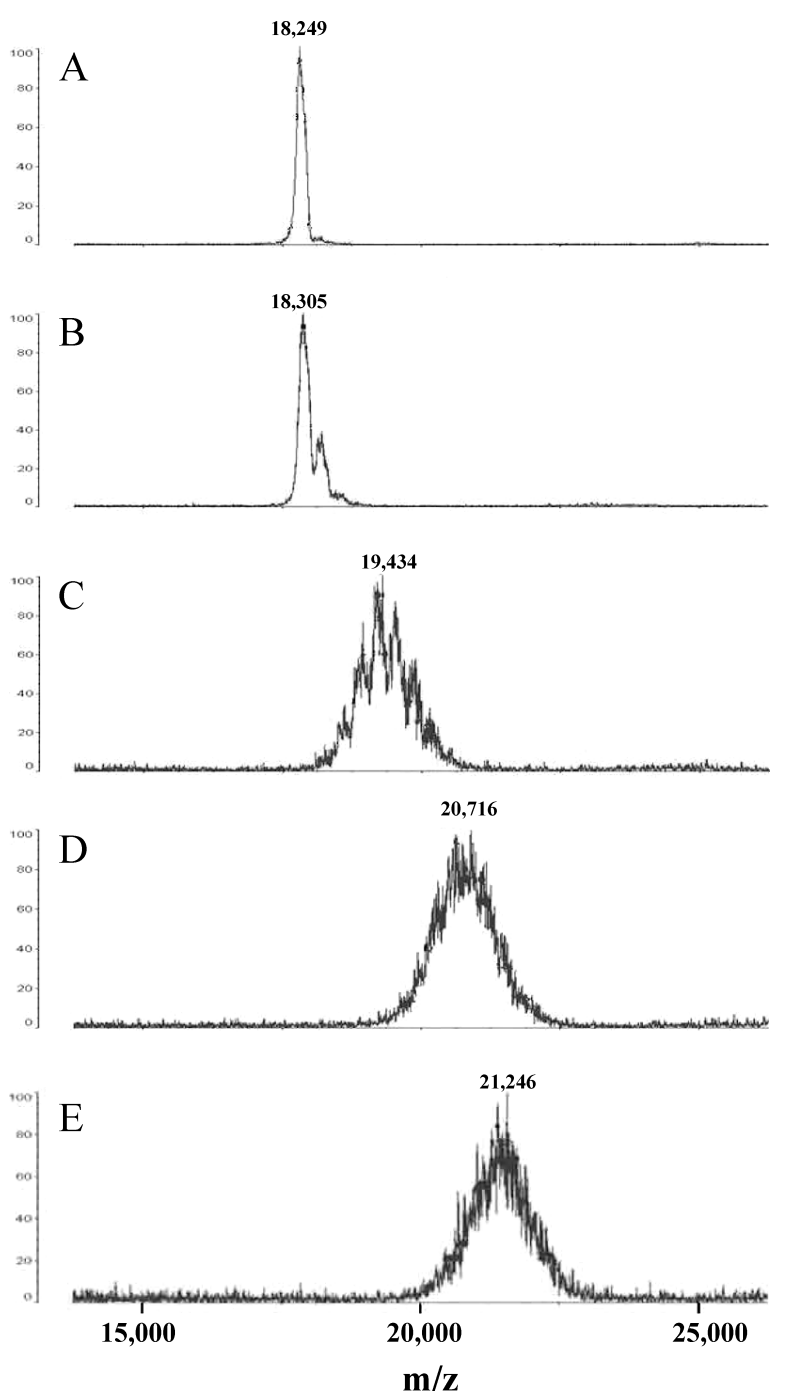

Fig. 2. Mass spectra of conjugated $\beta$-LG-xylobiose.

A, native $\beta$-LG; $B$ to $E$, the mixture of $\beta$-LG and xylobiose incubated for 0 (B), 1 (C), 4 (D) and 7 (E) days. 
A

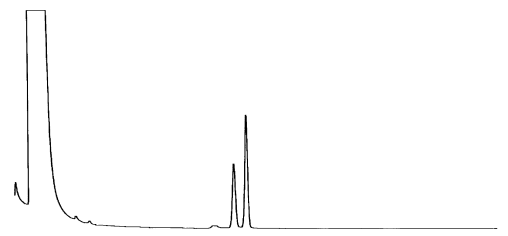

B

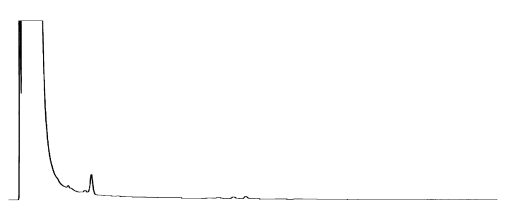

C

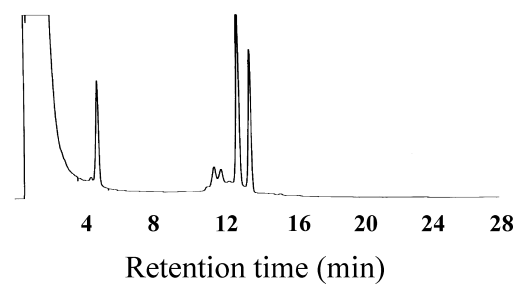

Fig. 3. Gas-liquid chromatogram of hydrolysate from conjugated $\beta$-LG-xylobiose.

$A, B$ and $C$ show xylose, hydrolysate from conjugated $\beta$-LGxylose, and hydrolysate from conjugated $\beta$-LG-xylobiose, respectively.

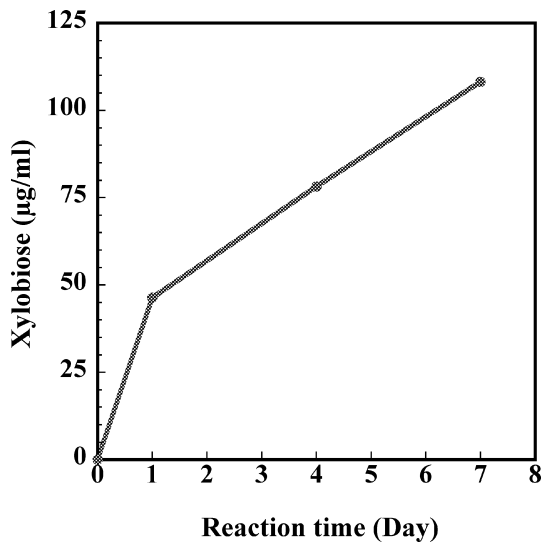

Fig. 4. Glycation of $\beta-L G$ with xylobiose by the Maillard reaction.

by trifluoroacetic acid (TFA) on GLC analysis (Fig. 3 B). The results indicated that the xylose observed was liberated from the non-reducing terminal of xylobiose, and that the xylosyl residue of the non-reducing terminal was not bound to $\beta-\mathrm{LG}$.

\section{Xylobiose content in conjugated $\beta-L G$-xylobiose.}

After removal of unreacted xylobiose by dialysis and ultrafiltration, sugar content was measured. As shown in Fig. 4, the amount of xylobiose in conjugated $\beta$-LGxylobiose increased with the reaction time, and $108 \mu \mathrm{g}$ of saccharide corresponding to xylobiose was determined in $1.0 \mathrm{mg}$ of conjugated $\beta$-LG-xylobiose after 7 days' incubation.

\section{Available $\varepsilon$-amino group content.}

The available $\varepsilon$-amino group content in conjugated $\beta$ LG-xylobiose was determined by spectrophotometric analysis using $o$-phthalaldehyde and $N$-acetyl-L-cysteine (Fig. 5). ${ }^{18)}$ The available $\varepsilon$-amino group content in conjugated $\beta$-LG-xylobiose decreased with reaction time. After

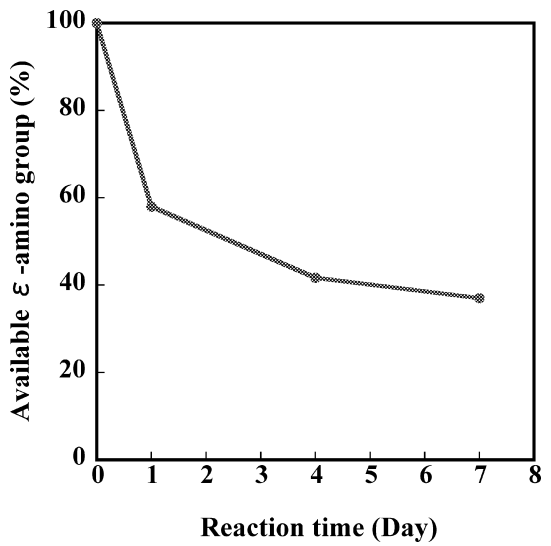

Fig. 5. Reduction of the available $\varepsilon$-amino group in $\beta$-LG by the Maillard reaction.

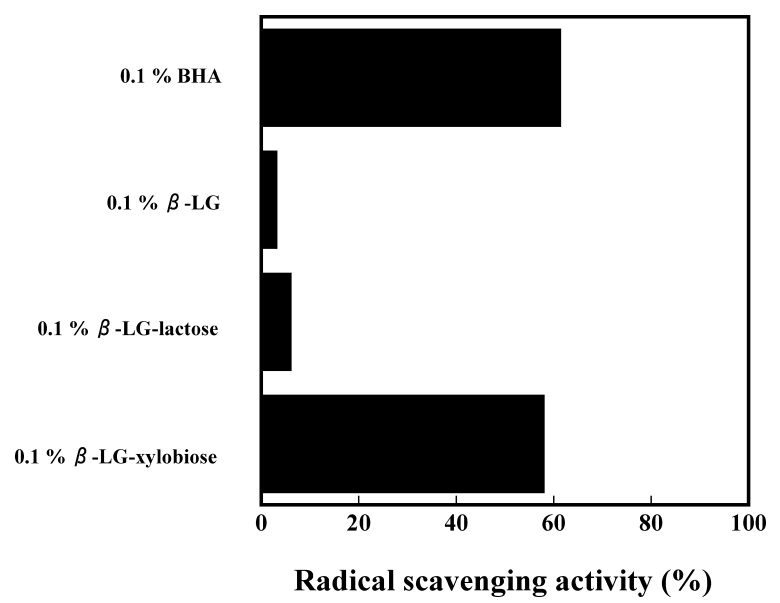

Fig. 6. Radical scavenging activity of $\beta$-LG-xylobiose measured by the DPPH radical scavenging test.

7 days' incubation, the available $\varepsilon$-amino group content decreased to $40 \%$ of that of free $\beta$-LG. The increase in the amount of xylobiose and the decrease in the available $\varepsilon$-amino group content of conjugated $\beta$-LG-xylobiose suggests the Maillard reaction occurred between the $\varepsilon$-amino group and xylobiose.

\section{Scavenging effects on DPPH radicals.}

The radical scavenging activity was measured by using DPPH radicals (Fig. 6). The radical scavenging activity of $0.1 \%$ conjugated $\beta$-LG-xylobiose was $58.1 \%$, while the radical scavenging activity of $0.1 \%$ free $\beta$-LG and $0.1 \%$ xylobiose were 2.3 and $3.8 \%$, respectively. These results showed that radical scavenging activity of $\beta$-LG was improved by the Maillard reaction with xylobiose. In comparison to the radical scavenging activity between conjugated $\beta$-LG-lactose $(5.3 \%)$ and conjugated $\beta$-LGxylobiose, conjugated $\beta$-LG-xylobiose showed much higher activity than conjugated $\beta$-LG-lactose (Fig. 6). Moreover, the radical scavenging activity depended on the concentration of conjugated $\beta$-LG-xylobiose (Fig. 7). The radical scavenging activity increased sharply from 0.01 to $0.1 \%$, although the activity increased moderately from 0.1 to $0.5 \%$.

Chevalier et al. ${ }^{13)}$ modified $\beta$-LG with arabinose and ribose, and they reported that the concentration of $50 \%$ of inhibition $\left(\mathrm{IC}_{50}\right)$ of $\beta$-LG-arabinose was $4.0 \mathrm{mg} / \mathrm{mL}$, while the $\mathrm{IC}_{50}$ of $\beta$-LG-ribose was $2.7 \mathrm{mg} / \mathrm{mL}$. In the present 


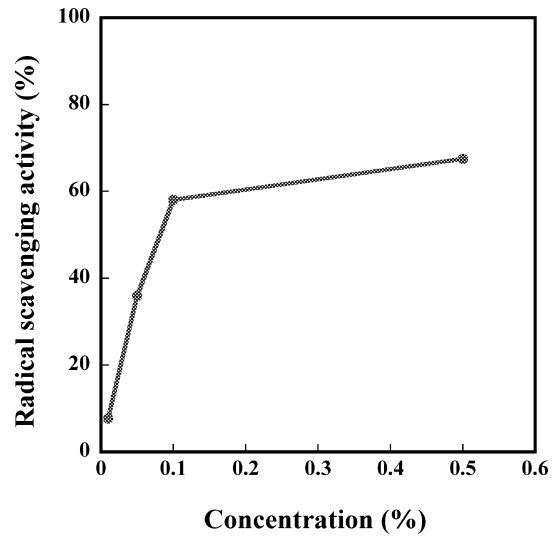

Fig. 7. Effect of concentration of conjugated $\beta$-LG-xylobiose on radical scavenging activity.

study, the radical scavenging activity of $0.1 \%$ conjugated $\beta$-LG-xylobiose was over 50\%. As shown in Fig. 7, the $\mathrm{IC}_{50}$ of conjugated $\beta$-LG-xylobiose was estimated to be about $0.08 \%$. The value was lower than those of conjugated $\beta$-LG-arabinose and conjugated $\beta$-LG-ribose.

On the other hand, the inhibitory ratio of conjugated $\beta$ LG-xylobiose on the oxidation of linoleic acid and rabbit erythrocyte membrane ghosts was also estimated in vitro. Surprisingly, no improvement of antioxidant activity of $\beta$ LG was observed with the Maillard reaction (data not shown). It is very interesting to investigate the mechanism of antioxidant activity of conjugated $\beta$-LG-xylobiose, because $\beta-L G$ and xylobiose had little antioxidant activity.

In this study, we found that $\beta$-LG was modified with xylobiose by the Maillard reaction, and that conjugated $\beta$ LG-xylobiose had a higher radical scavenging activity than free $\beta$-LG. We are now undertaking the investigation of the mechanism of the antioxidant activity of conjugated $\beta$-LG-xylobiose.

This work was supported in part by a Grant-in-Aid for Cooperative Research from Rakuno Gakuen University.

\section{REFERENCES}

1 ) M.E.C. Thomas, J. Scher, S.D. Banon and S. Desobry: Milk powders ageing: Effect on physical and functional properties. Rev. Food Sci. Nutr., 44, 297-322 (2004).

2 ) E. Dickinson and V.B. Galazka: Emulsion stabilization by ionic and covalent complexes of $\beta$-lactoglobulin with polysaccharides. Food Hydrocoll ., 5, 281-296 (1991).

3 ) M. Darewicz and J. Dzuiba: The effect of glycosylation on emulsifying and structural properties of bovine $\beta$-casein. Nahrung, 45, 15-20 (2001).

4 ) H.J. Kim, S.J. Choi, W.S. Shin and T.W. Moon: Emulsifying properties of bovine serum albumin-galactomannan conjugates. J. Agric. Food Chem., 51, 1049-1056 (2003).

5 ) C.A. Dunlap and G.L. Cote: $\beta$-Lactoglobulin-dextran: Effect of polysaccharide size on emulsion stability. J. Agric. Food Chem., 53, 419-423 (2005).

6 ) M. Hattori, Y. Aiba, K. Nagasawa and K. Takahashi: Functional improvement of alginic acid by conjugating with $\beta$ lactoglobulin. J. Food Sci., 61, 1171-1176 (1996).

7 ) M. Hattori, S. Miyakawa, Y. Ohama, H. Kawamura, T. Yoshida, K. To-o, T. Kuriki and K. Takahashi: Reduced immunogenicity of $\beta$-lactoglobulin by conjugation with acidic oligosacharides. J. Agric. Food Chem., 52, 4546-4553 (2004).

8 ) A. Nakamura, K. Watanabe, T. Ojima, D.H. Ahn and H. Saeki: Effect of Maillard reaction on allergenicity of scallop tropomyosin. J. Agric. Food Chem., 53, 7559-7564 (2005).
9 ) T. Aoki, S. Iskandar, T. Yoshida, K. Takahashi and M. Hattori: Reduced immunogenicity of $\beta$-lactoglobulin by conjugating with chitosan. Biosci. Biotechnol. Biochem., 70, 23492356 (2006).

10) I. Seiquer, T. Aspe, P. Vaquero and P. Navarro: Effects of heat treatment of casein in the presence of reducing sugars on calcium bioavailability: in vitro in vivo assays. J. Agric. Food Chem., 49, 1049-1055 (2001).

11) H. Jing and D.D. Kitts: Redox-related cytotoxic responses to different casein glycation products in Caco-2 and Int-407 cells. J. Agric. Food Chem., 52, 3577-3582 (2004).

12) U. Maitena, S. Katayama, R. Sato and H. Saeki: Improved solubility and stability of carp myosin by conjugation with alginate oligosaccharide. Fish. Sci., 70, 896-902 (2004).

13) F. Chevalier, J.M. Chobert, C. Genot and T. Haertlé : Scavenging of free radicals, antimicrobial, and cytotoxic activities of the Maillard reaction products of $\beta$-lactoglobulin glycated with several sugars. J. Agric. Food Chem., 49, 5031-5038 (2001).

14) H. Jing and D.D. Kitts: Antioxidant activity of sugar-lysine Maillard reaction products in cell free and cell culture systems. Arch. Biochem. Biophys., 429, 154-163 (2004).

15) M. Okazaki, S. Fujikawa and N. Matsumoto: Effect of xylooligosaccharide on the growth of Bifidobacteria. Bifidobacteria Microflora, 9, 77-86 (1990).

16) U.K. Laemmli: Cleavage of structural proteins during the assembly of the head of bacteriophage T4. Nature, 227, 680-685 (1970).

17) M. Dubois, K.A. Gilles, J.K. Hamilton, P.A. Robers and F. Smith: Colorimetric method for determination of sugars and related substances. Anal. Chem., 28, 350-356 (1956).

18) M.J.M. Hernandez and M.C.G.A-Coque: Available lysine in protein, assay using $O$-phthalaldehyde $/ N$-acetyl-L-cystein spectrophotometric method. J. Food Sci., 57, 503-505 (1992).

\section{メイラード反応を利用したキシロビオース糖化 $\beta$-Lactoglobulin のラジカル捕捉能の向上 矢島絈介 ${ }^{1}$, 小野寺秀一 ${ }^{1}$, 竹田保之 ${ }^{1}$, 加藤 ${ }^{\text {㘪 }^{1}}$

$$
\text { 塩見徳夫 }{ }^{1}
$$ \\ '酪農学園大学大学院酪農学研究科 (069-8501 江別市文京台緑町 582)}

メイラード反応を利用して $\beta$-lactoglobulin $(\beta-L G) に$, xylobiose を導入した。 得られた $\beta$-LG-xylobiose $の$ in vitro における抗酸化活性を $\beta$-LG-lactose と比較検討した７日 間の反応を行ったところ, $\beta$-LG-xylobiose の分子量は SDSPAGE 分析により 19-22 kDa と推定され, MALDI TOFMS 分析から約 $21 \mathrm{kDa}$ を中に多く分布していることが わかった。 ガスクロマトグラフィー分析を行ったところ， xylobiose が $\beta$-LGに結合していることが確認された。ま た， $\beta$-LG-xylobiose $1 \mathrm{mg}$ 当たり $108 \mu \mathrm{g}$ のxylobiose が結 合したと算出され，遊離 $\varepsilon$-アミノ基は約 $40 \%$ に減少した と算出された。DPPH を用いたラジカル捕捉能試験の結果 より， $\beta$-LG-xylobiose は $\beta$-LG よりも高いラジカル捕捉能 を有していることが明らかになり， $\beta$-LG-lactoseのラジカ ル捕捉能よりも高かった。この結果より, xylobiose は夕 ンパク質の糖化修飾における修飾糖として適したオリゴ 糖と考えられる，以上の結果より，メイラード反応を利 用したxylobiose 糖化修飾によって $\beta$-LGのラジカル捕捉 能が向上することが確認された. 